\title{
Christian Missionaries and Female Education in Bengal during East India Company's Rule: a Discourse between Christianised Colonial Domination versus Women Emancipation
}

\author{
Firoj High Sarwar \\ Research Scholar, Department of History (CAS), AMU, Aligarh, India.
}

\begin{abstract}
The paper shows the role of distinct western missionaries who were bringing Christianity in Colonised India as a path of female education, which implanted 'values of reformations', and 'individual's right' among the natives. These missionaries under the banner of 'Civilising Mission of White Men' instructed some modernizing process to the females of India within the framework of the 'Acceptance of Imperial British Rule'. In particular, I examined the role of distinguished devotees and private organizations of European Missionaries engaged in imparting female education in Bengal. Other hand, I have tried to assess the way of responses of Bengali girls and women to the 'New Education', which they received at the hands of missionary schoolmasters and schoolmistresses that produced an indigenous debate about Christian domination versus women emancipation. A very rich and suggestive literature is now appearing which examines the impact of modern schooling on Indian women and delineates ideological responses, particularly within Indian nationalist discourse. Finally, an attempt has been made to critically analyse the ideology and motives of the European women missionaries, and their limitation to the advancement of female education in Bengal.
\end{abstract}

Key Words: Missionaries, Zenana, Civilizing Mission, proselytize, Emancipation, Feminism

\section{Introduction:}

Empowerment with education of the women is an essential parameter of judging the standard of a civilised society. The growth and development of a community or civil society depends upon the growth and development of its individuals in general and the women in particular. There is no doubt about the fact that men and women are equal, but women have a vital role in the over-all development of the society and the nation. Women are equal partners in the overall growth and development of the family, community, society and humanity. Women almost in every social set-up play an important role either it is economic or political or cultural life of nation. Women have been given a position of pride in every religion. In Islam, Christianity, Hinduism and other religions they are respected and due importance is given to their role and rights. In the Holy Quran a complete Sura, "Sura-i-Nisa" is devoted for the role, welfare, rights and duties of the women. So, it is true that to pave a way towards an egalitarian society which based on gender quality, female education should be equalised with male education. But unfortunately which was yet be visible in Indian society. From that notion or something else (that is to be discussed in), in India, particularly in Bengal, the primary movement for female education started by Christian missionaries of European countries.

\section{Company's Government And Missionaries:}

There were main four missionary organizations, namely, Church Missionary Society of Scotland, Christian Knowledge Society of England, London Missionary Society of England, and Baptist Missionary Society of Danish. And naturally there were a number of devoted representatives of each organization, who carried out the female education mission, sometime individually and sometime through their organizations. These missionary personals, both in Home country and in Bengal knocked the door of British Government for necessary support. The colonial government, despite pressure exerted by missionaries and liberals, was some time unconcerned with female education. Basically Company's Government wanted to follow a policy of neutrality in the social matter of natives for so called 'colonial restriction' (means the basic but tentative rules and regulations that followed by the colonial agents in time to time to maintain colonial hegemony). But eventually, during the early decade of the $19^{\text {th }}$ century Bengali Society came into contact with the Western Ideas which began to penetrate the mind of native itself. Now, the western impact posed a challenge to the traditional social and cultural fabric of the country. As a result, the general reluctance of sending girls to schools gradually disappeared and in this new orientation of values and an urge for female education started off. In this context the missionary initiative in Bengal were especially accredited.

Some Christian were in India from the $4^{\text {th }}$ century, but with the advent of European colonised power in South Asia, Missionaries followed the flag and began the task of Proselytizing the 'heathens' of oriental world. The Portuguese and the Dutch in the 16th to $18^{\text {th }}$ centuries introduced their brands of Christianity to the regions 
they ruled in Asia, but it was with the subsequent British conquest in the $18^{\text {th }}$ century, that a new wave of missionary activity began, which was to have important consequences for local women. Earlier in a despatch of 1659, the Court of Directors had declared their earnest desire by all possible means to propagate the Gospel. After the battle of Plessey and assumption of wider powers by the East India Company; its several officers influenced by Christian views attempts (directly or indirectly) to proselytise the natives. Many of them settled in the little Danish colony in Serampore (Hugly Distict). In 1805, the Rev. Dr. Claudius Buchanan, government chaplain at Calcutta, issued a memoir on the expediency of an ecclesiastical establishment for British India, both as a means of perpetuating the Christian religion among our own countrymen, and as a foundation for the ultimate civilization of the Natives. Their zeal, out-running their discretion, brought them trouble in 1807; the Court of Directors issued a despatches dated the $17^{\text {th }}$ September 1808 , declaring strict religious neutrality. But sometime people like Marquis Wellesley gave encouragement to devout missionaries of every Christian persuasion.

In no field, however, did missionaries press their aims and purpose more consistently than in that of education. Since education was seen as one of the main ways to bring the brighten Indian into the light - and so to the Christian faith. In 1813 when company took upon itself a limited responsibility for education in India, it had been the orientalist school which held the field. Technically, for the dissemination of Christianity the Baptist Missionaries like J.C. Marshman, hold the knowledge of oriental languages was an instrument, not an end. The renewed charter of the Company had the new clause requiring the officers of the company to learn the native language to enable them to instruct Indian workers in a better way. This led to the need of establishment of the charity schools for both male and female at the Presidencies of Calcutta, Bombay and Madras. The alliances of the company's Government and Missionary enterprise had been celebrated in 1813 in the context of missionary educational programme through the Charter Act of 1813. Now, government time to time provided educational grant towards the assistance of missionaries or concertizing operations, as they exist at various stations throughout the presidency under the name of 'Grant-in Aid system'. But this benefited for no longer time, in 1844 the court of Directors in a despatch to the government the proposal of appropriation of educational fund to support of Christian institution was rejected.

In 1844 Lord $\mathrm{H}$ ardinge announced that English educated Indian would be given preference for government appointments. Free traders voiced their support for this policy believing it would develop an Indian population loyal to the British. Lord Dalhousie declared that no single change was likely to produce more important and beneficial consequences than female education. Sir Charles Wood, president of the Board of Control from 1853-55, issued an education despatch which focused on a total system of education insertion both sexes. The despatch read: "the importance of female education in India cannot be over-rated; and we have observed with pleasure the evidence which is now afforded of an increased desire on the part of many of the natives to give a good education to their daughters." By this means a far greater proportional impulse is imparted to the educational and moral tone of the people than by the education of men. In the second half of the $19^{\text {th }}$ century female education had been one of the most significant trends of 'New Education Policy'. Prior to the receipt of the despatch of 1854 from the Court of Directors, female education was not recognised as a branch of the state system of education India.

\section{Evangelical Personals And Their Role:}

The evangelical influence on education in Bengal was felt for the first time through the evangelical group of Chaplains headed by David Brown and Henry Martin and the Laymen Charles Grant, George Udney and Sir John Shore. In the $19^{\text {th }}$ century the British Administration in India adequately represented Clapham sect. C. Grant and Wilberforce enjoyed greater influences and their position was strong both in the India House and in the House of Commons. Actually they were the key maker of the Evangelical movement in Britain. Charles Grant wrote an influential work (1792) "Observation on the state of society among the Asiatic subjects of great Britain" particularly with respect to morals and on the means of improving it. This writing was a part of the evangelical attempt to pursued British parliament to require the company to open up its territories to missionary activity. Wilberforce in the Home Country instigated by Grant, proposed to introduced a bill with certain specific measures for the encouragement of missionaries and school masters for sending out to India, but it was vehemently opposed by other party in the Court of Directors

Later on, Trevelyan came straight out of the evangelical tradition of Charles Grand, believing firmly in a British mission to Christianised South Asia. He and Alexander Duff were in active in missionary education efforts. Trevelyan convinced his church Missionary society to adopt Duff's curriculum in its own local schools When Alexander Duff, the apostle of Scottish Calvinist Presbyterianism, arrived in Calcutta in 1830, among the first topics he heard discussed by the young graduates of the Hindu College was 'whether females ought to be educated'. Alexander Duff focused his evangelism on this group of young male upper-caste rebels and gained a few notable converts. The school which he established in proximity to the government-sponsored Hindu School and the Central Female School in Calcutta became a model for missionary educational enterprise. It was a 
deliberate strategy to penetrate Indian society from the top. Duff's school offered the sons of the upper classes a modern English-medium curriculum, required religious instruction. It was from this stratum of Indian society that Duff believed the influences of the 'Gospel' would filter down to the rest of society.

\section{Individual Role In Female Education:}

Mr. Kiernander, the first protestant missionary in Calcutta, came out in 1758. The first school established by the clergy for the children of indigent Christians was that by the Rev. Mr. Kiernander on the premises of the Old or Mission Church on the $1^{\text {st }}$ December, 1758 . He built a protestant Church on the $27^{\text {th }}$ May 1767 and the following year 175 children had been received education by him. The East India Company for a time lent a house for his school and church, and ultimately they were removed and he built houses for them in the present mission street (Calcutta). Later on, Sir Eyre Coote and his Lady evinced a great interest in this mission and provided financial assistance. In 1787 this church school become public and were transferred to the hands of the three trustees. There were many rival climates to the honour of having started the first girl's school in Calcutta. Writer Rainey says that the first girl school was established in 1760 by Mrs. Hedges. Other hand Captain Williamson mentions in his 'East India Vade Mecum' that Mrs. Hodges founded the first ladies seminary in 1780. Mr. Carey mention first girl school was established by Mrs. Lawson founded by 1812. A first charity school in Calcutta was set up in 1731 for the children of the Europeans in India. This school may be regarded as the beginning of the company's educational activities in India. Moreover Mr. Carey says in his 'Good Old Days of Hon. John Company' that the earliest school for young ladies was that of Mrs. Pitts. The writer of the 'Hartley House' (1789) mentions a girl's school conducted by Mrs. Savage, the only one in Calcutta, much in esteem with the Europeans. Another one was started by Mrs. Durrel that was situated in civil street and enjoyed the most extensive support. Mrs. Copeland opened a young ladies school in 1792. Here girls were taught reading and writing and niddle work. John Starsberrow opened a mixed school for boys and girls in a garden house at Mirzapore in 1785. Mrs. Payne also kept a boarding school for girl whom, it appears from an advertisement in the Calcutta Gazette, was removed to a house in Dacre's Lane in 1794. Mrs. Middleton took a house in 1799 at Dinapore for the tuition of both boys and Girl. During this time Mr. Carey founded a Missionary school at Dinajpore in 1794.

The beginning of the female education on the modern and organised line had also been made by the some Christian missionaries in Bengal. Mrs. Hanna Marshman and Mr. J. Marshman was the architect of this new venture. Mrs. Pearce and Mrs. Lawson founded a girls School in 1803 in Calcutta. Most probable it was for Christian converts and the plan was systematically carried out since 1817. The first independent women to come out of missionary work were Miss. Chaffin, a nurse, who arrived in 1813 in Bengal.

Missionary Pioneers like Mr. Robert May, Dr. J Marshman, Dr. W. Carrey, and Captain J Stuart set up several elementary educations for the promotion of Vernacular education among the natives. That was another step towards female education on a large scale also. The missionary plan of vernacular education received a valuable impetus with the publication of the Dr. J Marshman's Minute of 1813. Marshman's 'Minute', addressed to Rev. Fuller in England Soon after the passing of the Charter act of 1813, containing as it did a 'scheme for Lancastrian schools among the heathens'. Marshman was a teacher and he and his wife started schools for boys and girls, which become a centre of modern education. Mrs Hannah Marshman founded the first girl school in Serampore and another in Calcutta. According to First Report of the Native Schools of 1817, Serampore Mission of Dr. Carey, Marshman and Ward founded the first school of imparting instruction to Indian girls. The missionaries were interested in female education and schools for girls because, they argued, women indeed to be brought into the fold to make conservation permanent. But since man made the decisions, female education was ancillary. However, Indian intellectuals initially appreciated the educational mission of missionary organization by occasional donations and frequent participation.

La Martinie're College was found by the general Martin in 1836, who was French; he was in the service of the East India Company and become Major General. The School had two department one for boys and another for girls - affiliated to the B.A. standard of the Calcutta University. James Long's interest in Women's issues including female schools and education, appear to have gradually developed in the 1840's and pre-dates his marriage to Emily in 1848. His pain at the plight of widows and interest in the contemporary Bengali debates on the Women's liberty is clearly apparent in his journals. In this way in 1846, he discussed with Mr. Money, (collector of Krishnanagar) related the possibility of government involvement in establishing a girl School in Krishnanagar. He devoted a considerable amount of space to the aims, origin and development of female schools in the various Anglican missions throughout the Bengal presidency. The Rev B. Geidt, another Christian Missionary developed a similar scheme at Burdwan some years later along with the training of village schools children. Unmarried female missionaries arrived in India in the 1840s and were assigned to work with women and children, these missionary women, educated and eager to prove their worth, concentrated on covering adult married Indian women to Christianity. 


\section{Missionary Societies:}

This society founded in 1819, Society had established four schools at Gaurbere (Juvenile School), Janbazzar (Liverpool School), Chitapore Birmimham School) and Nandanbagh (Salem School), these schools were named after the name of lady patron. The Calcutta Journalgave a summary of the second report in which we fine the extent of the society's exertions in the matter of female education. The Government Gazette while summarizing the $8^{\text {th }}$ report of the society referred to its maintaining 20 schools at the time. The Calcutta Christian Observer reported that the society had renamed as Calcutta Baptist Female society for establishment and support of native female schools.. It had the honour of leading the way in native female education in Bengal and had established female School at such far off places as Katwa and Birbhum. Service rendered by the society to the cause of women's education in Bengal by setting up free schools for the poorer sections of the country was invaluable. It did pioneering work in the field of female education which was soon emulated by other societies. The first attempt to instruct native girls in Calcutta, in organised schools, was made by this Calcutta Female Juvenile Society. By the 1834 there were three schools under it, first one at Calcutta (containing 60 to 70 scholars) second at Chitpore (containing 110-120 scholars) and third at Sibpore, in which 20 children of native converts are instructed. The girls were taught reading, spelling and geography, and much attention is given to religious instruction.

\section{The London Missionary Society's Institution:}

It started educational work in Bengal began in 1798. There were Three Schools connected with the London Missionary Society in Calcutta (at, Thunthunnya Road, the Creek Row School, and Mendee Bagan School). The total numbers of Scholars were 108 in these schools in 1835. In 1854 it was transferred to a large and commodious building at Bhawanipur, consisting of a fine library, halls classrooms etc.

\section{The British and Foreign School Society:}

This Society in consultation with Mr. Haringhton (agent of Calcutta School Society) and Mr. Ward of Serampore Mission, both then in England, opened a subscription for the outfit of a mistress to be sent to India to instruct females born or breed in this country in the 'Lancasterian' method of mutual instruction, that they might afterwards diffuse the system throughout the country as opportunities offered. Miss Cooke (now Mrs. Wilson) accordingly arrived in November, 1821. Her services were engaged by the corresponding Committee of the church Missionary Society. Gradually she extended her labour and by 1824, there were 24 schools under her superintendents, attended on an average by 400 pupils. Eventually Committee formed a Ladies Society for Native Female Education in Calcutta and its vicinity. Subsequently the number of schools was increased to 30 (total pupils around 600). Some allowances was provided to women under the name of hurkarees, for collecting the children daily and bringing them to school. The Central School belonging to the Ladies Society instructed the 100 Native orphan girls in 1835.

\section{Church Missionary Society \& the Ladies Society:}

In connection with the Ladies' Society, there was also a girl's school on the premises belonging to the Church Missionary Society in Calcutta. The Ladies Society for Native Female Education in Calcutta and its vicinity'was founded under the auspices of Church Missionary Society in March 1824. The C.M.S. helps Miss Anne Cooke to start a network of free girls' school in Calcutta since 1821. Under her patronage many free primary schools for girl were set up at Thanthania, Sobhabajar, Mallikbazar, Krishnabazar, Kumartooly. The society was also got patrons like Lady Armherst (the wife of Governor General) and Mrs Ellerton. The leading citizen of the city took keen interest in the work of society.

The following list show the progress made by the promoters of the society in the cause of the female education between 1828-1827:

\begin{tabular}{|c|c|c|}
\hline Year & Number of Girls 'Schools & No. of Pupils \\
\hline 1822 & 8 & 200 \\
\hline 1823 & 15 & 300 \\
\hline 1824 & 24 & 400 \\
\hline 1825 & 30 & 500 \\
\hline 1826 & 30 & 540 \\
\hline 1827 & 30 & 600 \\
\hline
\end{tabular}


There was rapid increase in the number of schools and students of the ladies Societies that the citizens of the Calcutta were eager to take advantage of the new opening for female education in the city. As a result Society formed a Central female School in Calcutta. Along with the retirement of Mrs. Wilson in 1836 from Central School the importance of the operations of Ladies' Society had much diminished. In 1837 the superintendence of the Central Female School passed on to Miss Thompson and Mrs. White. By 1840 Ladies Society was only maintaining only three schools in Calcutta besides the central one, namely the Mirzapore School, Circular Road School and the Howrah School. In 1852 the activities of the society was confined to the support of the Central Female School in Calcutta, with six schools under its charge at Krishnagar. But at that time Society was paid attention to the organization of a Normal School for the training of the Christian Female Teachers. The local news paperpointed some references to the Excessive Christian zeal of the ladies society which ran counter to the deep-seated social values of the Hindu Society.

\section{Ladies Association:}

It was formed on January 14, 1825 with two distinct objects in view, to assist in building up a Central Female School and extent education among the Natives females of Calcutta. Mrs. Wilson was the president of the Association. The Ladies' Association for Native female education was originally instituted with a view to established schools for native's girls. At a time there were ten schools under its managements The Calcutta Church Missionary Associations has thirteen elementary Schools, partly in the town and partly in the villages instructed both Boys and Girls.

\section{The Bishop College:}

(Named after the first Indian Bishop of the Church of England) was founded by Incorporated Society for the Propagation of Gospel in Foreign parts in 1819. Chief architect of it was Dr. Middleton. The Society for the Promotion of Female Education in the East was established in 1834 for the same cause.

\section{The Society for promoting Christian Knowledge:}

This society also supported the cause of female schools through financial Assistances. Bishop Middleton took leading part in communicating with the government for the infrastructural development of these institutions.

\section{Bengal Auxiliary Society:}

In connection with the London Missionary Society this organization worked for the promotion of English Education among the natives. The Philanthropic Academy is and Institution, established by the Armenian Community of Calcutta. This institution included a Female Department. The College of St. Francis Xavier under the superintendent of Rev. F Chadwick (Patronised by Apostolic) also hold the class of English for girls.

\section{The Benevolent Institution:}

This institution founded in the year 1810 is supported by voluntary contributions, and was under the management of the Serampore Missionaries. The objective of the institution is to afford instruction to youth of both sexes, the decedents of indigent Christians of all nations. It was proposed at first to educated only 50 such children. The girls were taught reading, writing, spelling, grammar, arithmetic and needlework in addition to scriptural instruction.

\section{The Calcutta Catholic Society:}

Formed in 1830, it has established two charity schools each for both sexes. Both schools afforded daily instruction to about 150 children. Other side Calcutta Baptist Female Society was responsible in starting day schools for girls at Calcutta, Chitpore and Sibpore.

\section{The European Female Orphan Asylum:}

This was established for the reception and education of female European Orphans. The St. James's District day-schools for the instruction of the children of indigent Christian parents were four in number, the boys Schools, The girls Schools, Infant School and Sabbath School.

\section{The general Assembly's Institution:}

It was established by the active help of the General Assembly of the Church of Scotland. Dr. Alexander Duff, in 1830 not only established this institution but also imparted sound Christian instruction through the medium of the English language. Free Church of Scotland institution and Duff College traces its 
origin to the labour of Rev. Alexander Duff. It had both school and college department. He also opened an Orphanage, a Hindu Girls School and a Normal School. Mrs. Durel's Seminary for Girls attained in those days much celebrity.

\section{Serampore Missionary Society:}

A detailed report of the girls' schools conducted by the Serampore Mission has been mentioned in the Missionary Intelligence for February, 1828. These schools not only stated in and around Serampore, but also those at Beerbhum, Dacca, Chitagong and Jessore districts of Bengal. In January 1828, there were 12 Serampore Schools and the total number of students at 250. Most of these schools disappeared in course of time. The services they rendered to the cause of Women's education in Bengal were really immense. They are still remembered as pioneers in advocating the cause of female education in Bengal and stimulated popular interest in it.

The general survey of Missions in India, published in the Church Missionary Register for 1823, the following appears to be the number and distribution of the missionaries of the several associations. Church Missionary Society: 19, Christian Knowledge Society: 1, London Missionary Society: 11, Baptist Missionary Society: 30. In the beginning of 1852, the number of native Christian churches in India (including Ceylon) was 331. The number of missionaries was 443. Together with 698 native catechists belonging to 22 missionary societies, who have established 1347 vernacular day schools, 93 boarding, and 347 day schools for girls, 120's girl boarding schools, 126 superior schools, throughout the country. By 1851, in fact, Protestant missionaries were running 91 Anglo-vernacular schools and colleges. By 1851 there were total 1166 schools for boys and 371 for girls, and were teaching in some 64,000 students. Other hand Catholic Missionaries had work with schools in such places as Calcutta, Chittagong, Darjeeling and Dacca.

\section{Magnitude Of Female Education In Bengal Districts:}

Other than Calcutta, the missionaries' efforts to educate female in other districts of Bengal is considerable. Mr. Robert May, a Christian Missionary, in 1814 \& 1815, established several schools in Chinsura (Hogly District) that were also served for the female education. In 1818, there were 36 schools under his superintendence, attended by above 3000 Natives, and he established a girls' school in this district in 1818 . Basically these schools were financial supported by government but superintended by an L. M. S. Missionary till 1831. In Hughly District, Native Female Schools were begun by the Serampore missionaries at that settlement in 1823, and by 1835 there was the Central School containing 138 girls and Christian Village School containing 14 .

In Burdwan, the Church Missionary Society was active. The European ladies at Burdwan in connecting with the Calcutta Ladies' Society, supported two schools which had 60 to 80 girls in attendance in 1835, of which one situated at Japat in the Culna thana (its Superintendent was Mr. Alexander in 1836, 51 girls in 1835), another situated at the town of Burdwan under Mr. Linke. There were also third one situated on the Mission premises in the neighbourhood of Burdwan under (Mr. Weitbreeht), and fourth one at Cutwa, in connection with Calcutta Baptist Female School Society under William Carey. There was a girl school with about 30 scholars in 1835. In all these cases the wives of the missionaries co-operated in the superintendence. There was a girls' school at Baancoora District.

At Nudea district, The Church Missionary Society under Mr. Ward was so active in Educational field. At Kishnanagar in 1834, Ladies' Society had a Native Female School at which 40 girls of good family attended. At Dacca, Serampore Missionaries were in active. In the Districts of Dacca and Jalpaiguri, there were eight female schools in which 249 girls and young women were instructed in Bengali. It is estimated that in 1854, there were approximately 626 girls' schools in India (out of them in Bengal: 288) with a total of 21755 students. From the 1820 onwards, missionary girls' schools and convents were organised in almost every town of Bengal. Among those school, some provided education only in the local language to poorer section of the population, while other gave an education in English to daughters of upper and middle classes families. Towards the end of the 19the century these school mainly run by the new generation of western women graduates. They thereby created a group of westernised women qualified in English.

\section{Zenana School:}

Apart from the regular schools, women missionaries had the clear advantage in the connecting with the native was Zenana education for women at home. The system of sending of missionary women into Zenanas (women's quarter of the house) where women were secluded or denied access to education become acceptable to some wealthy who were interested in having educated wives. During the mid ninetieth century, the movement for home education in the Zenana developed fairly rapidly. In 1854, Rev. John Fordyce of the Free Church Mission convinced some Hindu rich Bengali to pay for their instruction of their women at home by his ablest teachers. In the second half of the $19^{\text {th }}$ century, the Zenana schools gradually developed into a regular form. But 
this education could only have a very limited success in terms of conversion. They wanted privatization of female education at home without the Christianity. Basically the missionaries' main interest was to reach out through education and Christianised of upper level of the society. The limited success they had in Zenana education led to a reconsideration of the policy in favour of more generalised female education of all classes. Therefore, in next stage we saw a nationwide programme of female education in India in the second half of the $19^{\text {th }}$ century.

Alexander Duff had said about Zenaan education:

"The beginning of national Female Education must be amongst the higher classes, and that beginning must be by means of domestic instruction... If then we were shut up to the exclusive use of public education, we should be reduced to the conclusion that the prejudice cannot be removed until the females be educated, and that the females cannot be educated until the prejudice be removed. From this dilemma the only hope of deliverance is held out by domestic instruction."

\section{Hindrance Before Female Education:}

The missionary schools for the girls had not been popular with the educated classes even in the middle of the $19^{\text {th }}$ century. A correspondence from Chinsura wrote about the missionary schools for girls: "A few Benevolent European gentlemen and ladies, indeed, made some attempt to introduce female schools, but they have failed, excepting in one or two places, where a small number of the very lowest classes attend schools for the sake of clothing and other rewards". Respectable Hindu Gentlemen belonging to the upper classes of the society would not send their girls to public schools. In the Report of the State of Education in Bengal (1836) Wilma Adam wrote: 'A superstitions feelings is alleged to exist in the majority of the Hindu families, principally cherished by the women and not discouraged by the man, that a girl thought to read and write will soon after marriage become a widow. At the beginning of the nineteenth century, female literacy was extremely low in relation to male literacy. The education of the girls' was managed by the enterprising individuals and private organizations and even in the $18^{\text {th }}$ century there were quite few educated women among the higher castes. This certainly true of those orthodox Hindus, who latter, in the 1840s and 1850s, established English schools to combat the effects of the missionary schools; conceding that the demand for English education would not diminish because "Knowledge of English.......paves the way to wealth; they demand it wise to found their own English schools where students could get on with obtaining 'a money making knowledge' without their losing their faith". At that time there was also a belief that literate girls would be early widows. Respective people could not send their daughter to schools run by the missionaries. This meant that at first only the "very poorest and lower castes' would enrolled in the schools.

Given this well established litany of female degradation, it is not surprising that the reasons adduced by missionaries for taking girls into their care and giving them simple literacy skills were couched in the language of moral rescue. Nearly all early efforts were aimed at 'the lowest grades of native girls' and consisted of little more than spelling, reading from the Bible, and needlework. These day classes were a deeply frustrating affair from the missionary standpoint. It was frequently necessary to pay small sums to children to entice them to attend. Few stayed long enough to acquire more than the rudiments of literacy and fewer still long enough to absorb the Christian influence that was the missionaries' aim. When a pupil did profess Christianity, other parents withdrew their children from school, local patronage was withheld, and schools closed for lack of pupils. This was often attributed to the Christian religious content of the schooling; yet the few indigenous schools that were started fared little better than missionary ones. As resistance grew among high-caste Hindus to schooling for their daughters, and when the Central School, the first focused effort to reach upper-class girls, located on Cornwallis Square (Calcutta) in the centre of the 'most respectable Hindoo population' failed to attract 'respectable girls'. Gradually, missionaries shifted their efforts to boarding schools for Eurasian children and orphans, the majority of whom were female. The work of female education in the first decades of the nineteenth century remained rescue work among the marginal communities of India, and it was largely on this basis that the early appeals for support from Great Britain and from the European communities in India were made. However, a group of Anglo-Indian women educated by the Baptist Missionaries firstly and then gradually disseminated towards different section of the society.

The wives of the missionaries established 'Zenana' schools. But here they were confronted with a number of difficulties. First local custom disfavoured the practice of school going among the married ladies; secondly, a difficulty was posed in the matter of fixing school hours for married ladies, and thirdly such married ladies as were available for instruction attended schools for some months and days only. The result was that there was very slow progress in female education. Though the efforts of the missionaries in this regard meet with failure, they deserve appreciation as the trail blazers of female education in Bengal. 
Initially these missionary schools enjoyed the patronage of Hindu Gentlemen and were staffed by Brahman pundits. But they failed to attracted girls from the higher castes. The religious instruction deterred prestigious families while pupils from the lower classes or Christian families were lured to the school by gifts of clothing and other items. The morale and financial support of the Colonial authorities was essential to the spread of female education, but did not guarantee schools for girls. Indian norms and social customs made the British model of schooling difficult, if not impossible. Deeply ingrained notions of sex segregation and, in some areas, of complete seclusion, meant girls had to have female teachers and study in separate institutions. There was another set of problems associated with the institutions for female education. Indians were unaccustomed to sending their daughter to schools yet this was the only practical method of accomplishing the task. In actually, Zenana Education - Education Given in the home - was expensive, cumbersome, and largely ineffectual.

Alexander Duff had been certain that not much was to be expected of female education in the first phase of westernization. 'A generation of educated males must be the precursor of a generation of educated females', he wrote in 1836. Once fully articulated, this ideology provided the rhetorical strategy for recruiting in the next decades hundreds of British and American women into the Zenana Missions movement.

\section{Christianization Versus Emancipation:}

Before discussing this discourse, I would like to pointed out the statement of Priscilla Champan, related to Hindu female education that "the poor idolatrous females in bondage" and the "the necessity of an avowed Christian direction" to the efforts which may effects the elevation of the Hindu females from their present degradation to their proper level. Though the contemporary scenario of Bengal society was in against female education, and of course, at first missionaries under Christian principle was lighting the female towards education. But it was not necessarily become virtual for next stage of education. Under the banner of the civilising mission that followed by the Rudyard Keepling's theory of 'White Man' Burden', European missionaries walked through the oriental world. Particularly, Western women in the colonised world were expected to play subordinate role and help the white man with his very masculine burden of the ruling empire". Kumari says that 'I came across numerous example of dynamic foreign women who were linked to nationalists, socialists, reformists, missionary and medical projects in South Asia.'

Over the last decade and a half, feminist scholars have focused on the involvements of white women in the British Empire and on the nature of their location and agency in the processes of colonial domination more generally. A number of these studies emphasize white women's active agency in constructing a gendered colonialism: the white women's burden to bring civilized femininity to their 'other' sisters. This 'burden' was most often articulated as a 'mission of sisterhood' to emancipate 'other' women into the freedoms of metropolitan norms of femininity and womanhood.

Rendered in its secular form, as Antoinette Burton has convincingly argued, that the 'mission of sisterhood' enabled British first-wave feminists to 'claim their place in the empire' and argue for the feminist political agenda as an essential consolidation of imperial claims to superior civility. In its religious guise, the 'mission of sisterhood' was a vital strand of the British missionary movement's discourse, variously used to galvanize public opinion in support of the evangelical agendas of empire and to articulate the necessity for a specifically female effort in foreign missions: to emancipate - both socially and spiritually - their heathen 'sisters'.

Missionaries, nuns, social reformers felt that they had a morale duty to uplift, disinfect and modernised traditional society through the Christianity and 'civilizing mission'. In doing so they often had to fight their own male hierarchies of society. But who are the women missionaries in the 'Age of Empire'? Barbara Ramusack described them as maternal imperialists "mothering India and Indians". Antoinette Burton called them 'imperial feminists', who collaborated in the ideological work of Empire. Other hand, Missionaries have been generally looked upon with hostility by the non-Christian intelligentsia of India, even through many of them benefited from the service offered by these foreigners. These missionaries have been stereotyped as racist 'agent of imperialism', at worst, and well - meaning but ridiculous proselytizers at best, who along with Christianity were offering some tempting products of western society. So is very obvious that the missionaries tried to established both cultural and political domination upon Indian.

Protestant Christian missionaries created a fully articulate ideology of female education in colonial India in the 1830s and 1840s, several decades before large numbers of British and American women entered the mission field to carry out the enterprise. In seeking a rationale for their educational mission among women in India, these educational pioneers naturally drew upon ideological formations of gender then current in Britain. But they were working in a colonial context, and the females they sought to educate were 'different' from British females. Indian women were 'known' to these missionary practitioners both from direct experience and from the constructed knowledge about Indian society developed over nearly a century of colonial domination. Thus a major obstacle to the transfer of British ideas about gender and the appropriate education for females to a colonial context was the vast difference of race and culture posited in that discourse and insisted upon in the 
evangelical purposes of the missionary enterprise. It was also in this period of the so-called 'Bengal Renaissance' that an intellectual climate was present, particularly in Calcutta, which seemed ripe for a new initiative in female education. By the 1840s missionaries were able to draw upon a deep-rooted British domestic ideology, itself greatly influenced by evangelical understandings of proper gender relations, which outlined separate spheres for the sexes and dole out new social significance to the role of women missionaries in the domestic sphere. Several missionaries, who were selectively accustomed to elements in both the Indian and British settings, fashioned an ideological justification for female education out of these elements, and they did so with a keen eye to the strategic importance of female education in their own scheme of cultural transformation.

Women played a crucial role in almost all arenas of protestant and catholic missionary endeavour. Most important were the single, independent women missionaries or nuns who from the early $19^{\text {th }}$ century onward began travailing to Asia and Africa. This group formed a vanguard that started women's groups, girls' schools, orphanage and convents, and were able to enter the homes of married or secluded women to teach languages and the other skills and, it was hoped to spread the gospel and later years missionary women doctors pioneered female medical education. Women missionaries and nuns also had their own network of female support, locally and internationally. In Britain, the Ladies' Association for promotion of female education among the heathens' was formed in 1866 with its own founding staff and magazine; the objectives were to recruit women as teachers who could help in the education in the girls and to support girl's schools .

The influences of missionaries on local women and the way in which Christian education produced not only "good wives and mothers" but also the early women professionals, feminists and social reformers, proved very effective. The network of the girls schools in India started by the European missionaries that provided a modern western education and unintentionally produce the Indian "new women". Those western women, Ramusack call them 'secular missionaries' who took up issues of social reform, education and the liberty of women. They often had to fight on two fronts: against the colonial govt, that paid lip-service to reform but was reluctant to disturb local opinions, and against those Indian who thought legislation by the British, and denunciations by outsiders of various social evils, were an unbearable interference in the sacred area of family life.

But whatever their enthusiasm and commitment to female education and social reform, these western women missionaries, could not enter the pantheon of white goddess as long as they worked either within the ideological framework of Christianity and Christian culture, or with a belief in the compassion of British rule. Under the British rule, women missionaries found space in the public domain and opportunities for achievement denied them at home. While they spearheaded movement for Christianizing Asian societies through the education of women, many questions were raised about their motives, and the kind of education provided. Was it patriarchal, puritan, riddled with middle class values and supportive of imperialism or was it liberating, freeing local women from feudal constraints and traditional social protection oppressive to women? Were Christian keeping women subordinate by creating "good wives and mothers" or were they championing women's right to education and promoting ideas of equality? The Christian impact on Indian Society in late $18^{\text {th }}$ century was linked to the imposition of a system of production and exchange relation designed to serve imperial interest. In this context, Christianity had a dual work - 'Conversion' and 'Modernization'. In the first role, missionaries claimed that they were bringing salvation light of true faith to people in the darkness of the devil. In the second role, missionaries contributed to the breakdown of traditional beliefs and social structure, imposing western system and values on local societies.From the earliest year of the missionary activity it was understood that Christianity and western values formed a superior and joint product to be imposed on heathens whose 'barbaric' and 'savage' way of life was a result of phony faith? Christianizing natives meant attacking their religion and social protection and presenting after natives at both ideological and institutional levels.

The evangelicals advocated confrontation not only to Christianised 'heathens' but also to introduce them to concepts to the rights of men, to a better materials life and to western education. The main concern of the women missionaries was the amelioration of the lives of colonised women, but in the 'Age of Empire' Christianity was linked with the imperialist conquest and capitalist expansion and the main current of missionary's activity become identified with colonial rule. Missionary women were also part of the feminization of Christianity. The increase of female educational opportunities and the challenges all spheres of life. This wide Missionaries and Nuns very conscious of their status of local women, and their work for women in health and education reflected awareness about women's problems. The missionaries lasting contribution was the unintentional creation of a 'feminist' consciousness. They gave equal educational facilities at all levels to girls and introduced a curriculum that promoted higher education including university education for women. Education is the one common issue which unites all of these women, viewed by them as the key factor in the emancipation of South Asian women. 
Women involvement in the foreign missionary movement was almost entirely galvanised around issue to do with the social and spiritual emancipation of the Indian women from the middle of the nineteenth century, particularly 'female education', reflected in the title of the first dedicated women's missionary organization in Britain. Schooling was part of missionary practice from the beginning of the missionary enterprise, but during the early stages the education of girls was unsupported by an articulate ideology beyond the evangelical imperative itself and the assumed value of basic literacy for Bible reading. In the colonial setting, where reception of the Christian gospel had to be reconciled through a labyrinth of linguistic and cultural misunderstandings, mission schools provided a place where a new culture based on the ability to read the Christian scripture could be inculcated. Missionary wives undertook to provide simple schooling for a few young girls in the vicinity of mission stations almost as a matter of course. Soon missionaries were sending back reports to Britain of the abject condition of Indian females, thus participating in what might be considered the last stage of a well established manners, customs, and ceremony literature in which the condition of females was used as a touchstone of the colonial evaluation of indigenous culture. For nearly a century European writers from Halhed to Charles Grant and James Mill had repeated a long list of atrocities perpetrated on Indian women as signs of the degenerate nature of Hindu culture. So when missionaries began to contemplate the education of females, they started from a fixed image of the destitute Indian woman already well established in Indological discourse.

\section{Conclusion}

After considering all negate and plus points, I think that the Western Christian Mission adjusted according to contemporary polity-socio circumstances and rendered their services accordingly. Consequently, it had the effect of stimulating the growth of philanthropy of varied kinds; it gradually become a force for rousing an "enthusiasm of humanity." In India, However, the humanitarian work for the missionaries was 'a direct result of their fervent desire to promote Christianity'. The main aspects of their social work were undertaken as aids to and almost inevitable expression of their main task of evangelization. The missionaries were trained with primarily for the work of proselytization but they rendered humanitarian services to show that Christianity as a human religion, therefore superior to others in India. By the middle of the nineteenth century an argument emerged that the education of the female was essential for the purpose of transforming national character. It begins to appear often, expressed as a common sentiment, in government education reports. It occurs in the testimony given before the House of Lords Select Committee which preceded the renewal in 1853 of the East India Company charter and the Education Despatch of 1854. It also appears in the despatch itself... 'The importance of female education in India cannot be over-estimated'. By this means a far greater proportional impulse is imparted to the educational and moral tone of the people than by the education of men.

\section{Primary \& Contemporary Sources:}

\section{References}

[1] Sharp, H. 'Selection from Educational records, part 1, 1780-1839,' Superintendent Government Printing, Calcutta, 1920.

[2] Mahmood, Syed. 'A history of English education India: Its rise, development, Progress, Present Condition and Prospects being a narrative of various phases of Educational Policy and Measures adopted under the British Rule from its beginning to the present period, (1781-1839), Idarah-i-Adabiyat-i, Delhi, first pub. 1895

[3] Despatch from the Court of Directors to the presidency government, dated $24^{\text {th }}$ August, 1844

[4] Charles Wood' Educational Dispatch, $19^{\text {th }}$ July, 1854

[5] Report From the House of the Commons on the affairs of the East India Company, $16^{\text {th }}$ August, 1832, general Appendix I.

[6] Duff's letter to Baptist Noel, 19 November 1836, which is printed in an appendix to Noel, Duties of Christians.

[7] Carey, W. H., 'The Good Old Days of Honourable John Company; Being Curious Reminiscences during the Rule of the East India Company from 1600-1858', Quins Book Company, Calcutta, first pub. 1882

[8] J. C. Marshman, 'Life and Times of Carey, Marshman and Ward', vol.2, London, 1859

[9] C. M.S., C11/0 185/115 JOURNAL $3^{\text {rd }}$ May 1846

[10] C. M.S., C11/0 185/115 JOURNAL $28^{\text {th }}$ May 1846

[11] C. M. S. C11/0 115/16 Annual report 1857

[12] The Calcutta Journal, March 11, 1822

[13] The Government Gazette, June 25, 1829

[14] The Calcutta Christian Observer, December, 1832

[15] Adam, William' Reports on the state of Venacular Education in Bengal and Bihar, 1835, 1836 \& 1838 , [edit.] by Basu, Anathnath. University of Calcutta, 1941

[16] Reformer, December, 19, 1831

[17] Church Missionary Register, 1823

[18] Report from the House of the Commons on the affairs of the East India Company, $16^{\text {th }}$ August, 1832, general Appendix I

[19] Report of the General Committee of Public Instruction, No. 1310-1313, 18.1.1832

[20] Fordyce, John 'Emancipation of Woman in India', Calcutta Christian Observer 1 (January 1855)

[21] The Calcutta Review (September 1855)

[22] Samachar Darpan, March 3, 1833

[23] Letter from Duff, 19 November 1836, printed in appendix to Noel, Duties of Christians.

[24] Report of House of Lords, Select Committee. 1852-1853 Sessions, paras 5817, 6818, 7436 


\section{Secondary:}

[1] Kipling, Rudyard. "The White Man's Burden" Popular Magazine McClure, 1899, USA

[2] Murshid, Ghulam. 'Reluctant Debutante: Response of Bengali Women to Modernization, 1849-1905, Sahitya Samsad, Dhaka, 1983

[3] Borthwick, Meredith. 'The Changing Role of Women in Bengal, 1849-1905' Princeton University Press, Princeton, 1984

[4] Ahmad, A. F. S. 'Social Ideas and Social Changes in Bengal', 1818-1835, Calcutta, 1969

[5] Jayawardena, Kumari. 'The White Women's Other Burden: Western Women and South Asia during British Rule', New York: Routledge, 1995

[6] Martin, R. Montgomery, 'British India, its History, Topography, Government, Military, Defence, Finance, Commerce and Staple products', Mayur Publications, Delhi, 1855

[7] Renford, Raymond K., 'The non-officials British in India to 1920', Oxford University Press, Delhi, 1987

[8] Chauhan, C. P.S. 'Modern Indian Education: Policies, Progress and Problems', Kanishka Publisher, New Delhi, 2007

[9] Sumit Sarkar \& Tanika Sarker, ed. 'Women and the social reform in India; A Reader', an article by Geraldine Forbes, 'Education for women', Volume 1, Permanent Black, 2007

[10] Richey, J. A. [edit.] 'Selections from Educational Records of Government of India: 1840-1859', part 2, Calcutta. 1920

[11] Acharya, Srikumar. 'The Changing Pattern of Education in Early Nineteenth Century Bengal', Punthi- Pustak, Calcutta, 1992

[12] Zaztoupil, Lynn. \& Moir, Martin. Edit. 'The Great India Education Debate; Documents relating to the Orientalist - Anglicist Controversy, 1781 - 1843', Curzon Press, , Richmond, 1999

[13] MacCully, Bruce. 'English Education and the origin of Indian Nationalism', Gloucester, Mass Peter Smith, 1966

[14] Gauri, Viswanathan. 'Masks of Conquest: Literary Study and British Rule in India', Columbia University Press, New York, 1989

[15] Renford, Raymond K., 'The non-officials British in India to 1920', Oxford University Press, Delhi, 1987

[16] Deb, Raja Binaya Krishna. 'The early history and growth of Calcutta' [edit.] by Subir Ray Chaudhuri, Rddhi, Anu Press, Calcutta, 1905

[17] Rainey, H. James. 'Rainey's a Historical and Topographical Sketch of Calcutta', Sanskrit Pustok Bhander, Culcutta, 1986

[18] Nath, Narendra. 'Promotion of learning in India by early European settlers', Longmans, Green and Co., London, 1915

[19] Potts, E. D. 'British Baptist Missionaries in India (1793-1837): the history of Serampore Missions', Cambridge, 1967

[20] Mukherjee, Ramakrishna, 'Rise and fall of the East India Company - A Sociological Appraisal', Popular Publisher, Bombay, first edition 1955

[21] Harihar Das, 'Life and Letters of Toru Dutt', London, Humphrey Milford, 1921

[22] Bagal, J. C. 'Beggining of Modern Education In Bengal: Women' education', Calcutta, 1944

[23] Lushinghton, Charles. 'Histories, design and present state of the religious benevolent and charitable institution', Calcutta, 1824

[24] Wilson, H. H., 'History of British India from 1805 to 1835 ', Vol. II, James Madden, London, 1990

[25] Dutta, K.K. 'Education and Social Amelioration of women in pre-mutiny India, Patna, 1936

[26] Mathur, Y. B. 'Women's education in India, 1813-1966', Asia Publication, Bombay, 1973

[27] Davidoff, Leonore. \& Hall, Catherine. 'Family Fortunes: Men and Women of the English Middle Class, 1780-1850', Hutchinson and University of Chicago Press, London and Chicago, 1987

[28] Bina $\square$ a Bhūsha $\square$ a Rā $\square$,aPranati Ray, 'Zenana mission: the role of Christian missionaries for the education of women in 19th century Bengal', Indian Society for Promoting Christian Knowledge, University of Michigan, 1998

[29] Lahiri, 'Krishna. 'Education of Women in Bengal, 1849-1882' (Ph.D. diss., University of Pennsylvania, 1979)

[30] Priscilla Chapman, 'Hindoo Female Education', R. B. Seeley and W. Burnside, London, 1839

[31] Bagal, J. C. 'Women's Education in Eastern India: The First Phase', The World Press, Calcutta, 1956

[32] Fuller, Margaret. 'Woman in the Nineteenth Century', Dover publication. 1999

[33] Callaway, Helen. 'Gender, Culture and Empire: European Women in Colonial Nigeria', London: Macmillan. 1987

[34] Burton, Antoinette 'Burdens of History. British Feminists, Indian Women, and Imperial Culture', 1865-1915, Chapel Hill \& London: University of North Carolina Press, 1994

[35] Anon. 'History of the Society for Promoting Female Education in the East', London: E. Sutter, 1847

[36] Laird, M.A. 'Missionaries and Education in Bengal, 1793-1837, Clarendon Press, Oxford, 1972

[37] Inden, Ronald. 'Imagining India', Basil Blackwell, Oxford, 1990

[38] Brian Heeney, 'The Women's Movement in the Church of England, 1850-1930', Clarendon, Oxford, 1988

[39] Dutta, Kalikinkar. 'Survey of Indian social life and economic condition in eighteenth century (1707-1813), Calcutta, Firma K. L. Mukhopadhyaya, 1961

[40] Bhatt B. D. and Aggarwal J. C. [edit.] Educational Documents in India, 1813-1977, Arya Book Depot, Delhi, 1977

\section{Journals and Newspapers:}

[1] Haggis, Jane. 'Ironies of Emancipation: Changing Configurations of 'Women's Work' in the 'Mission of Sisterhood' to Indian Women' (Reviewed work), Feminist Review, No. 65, 'Reconstructing Femininities: Colonial Intersections of Gender, Race, Religion and Class' (Summer, 2000), Palgrave Macmillan Journals.

[2] Kosambi, Meera. 'Indian Response to Christianity, Church, and Colonialism: Case of Pandita Ramabai', Economic and Political Weekly 27 (24-31 October 1992)

[3] Education (News paper), Tuesday, March 29, 2011

[4] Calcutta Review, July, 1913

[5] Forbes, Geraldine. 'In Search of the "Pure Heathen": Missionary Women in nineteenth century India', EPW, $21, \mathrm{NO} .17$ (26 April 1986)

[6] Rowbothm, Judith. 'Hear an Indian sister's plea - reporting the work of 19th-century British female missionaries' Women's Studies International Forum, Vol. 21, No. 3, 1998

[7] Savage, David. 'Missionaries and the Development of a Colonial Ideology of Female Education in India' , Gender \& History, Vol.9 No.2 August 1997

[8] Steve Bishop 'Protestant Missionary Education in British India' Evangelical Quarterly 69:3, 1997

[9] Wilson-Moore, Margot. (1998) Book Review: "The White Woman's Other Burden: Western Women and South Asia during British Rule"," Journal of Hindu-Christian Studies: Vol. 11, Article 18

[10] Bhabha, 'The Other Question—the Stereotype and Colonial Discourse', Screen 24, (1983) 